\title{
DETERMINING FRACTURE RESISTANCE OF STRUCTURAL ADHESIVES IN MODE-I DEBONDING USING DOUBLE CANTILEVER BEAM TEST
}

\author{
ODREĐIVANJE LOMNE ŽILAVOSTI \\ KONSTRUKCIJSKIH LJEPILA PRILIKOM \\ ODLJEPLJIVANJA U MODU-I POMOĆU TESTA \\ DVOSTRUKE KONZOLE
}

\author{
Ivan Hlača*, Marin Grbac*, Leo Škec*
}

\begin{abstract}
Double cantilever beam (DCB) test is the most commonly used test for determining the fracture resistance of structural adhesive joints in mode-I debonding. Test specimens are composed of two equal plates that are glued together, and then exposed to the opening load causing crack propagation along the bonded surface. During the experiment, loadline displacement, applied force and crack length are measured continuously. Using these data, the fracture toughness of the adhesive can be computed by the procedure given in the relevant ISO standard (BS ISO 25217:2009). The calculations are based on simple beam theory and linear elastic fracture mechanics (LEFM) equations. In this paper, we will present the standard method for performing a DCB test and the method for data processing required to obtain the adhesive fracture toughness, i.e. the critical energy release rate. Experiments are performed for SikaPower $\AA 4720$ adhesive, applied with controlled thickness between the aluminium plates (adherends). After the curing period recommended by the adhesive manufacturer, DCB specimens with piano hinges are loaded by a tensile-testing machine. Loading is applied in the displacement-control mode because when the crack starts to propagate, the applied load drops. Using the optical measurement system GOM Aramis, complete displacement field is recorded during the experiment. Displacement field is then used to obtain the actual load-line displacement of the adherends (different than the one recorded on the tensile-testing machine grips) and the position of the crack tip. After syncing the measurements from different devices, fracture toughness for the adhesive is determined and a statistical analysis performed.
\end{abstract}

Key words: double cantilever beam (DCB), linear elastic fracture mechanics (LEFM), test method, mode-I delamination, fracture toughness

\footnotetext{
* University of Rijeka, Faculty of Civil Engineering, Radmile Matejčić 3, 51000 Rijeka E-mail: \{ivan.hlaca,marin.grbac,leo.skec\}@gradri.uniri.hr
} 


\section{Sažetak}

Test dvostruke konzole (eng. Double Cantilever Beam (DCB) test) je najčešće korišteni test za izračun lomne žilavosti u modu I kod konstrukcijskih lijepljenih spojeva. Testni uzorci se sastoje od dvije jednake pločice koje se prvo međusobno zalijepe, a zatim izlože opterećenju, što uzrokuje širenje pukotine duž ljepila. Tijekom eksperimenta kontinuirano se mjeri pomak, sila i duljina pukotine. Koristeći ove podatke, lomna žilavost ljepila se može izračunati prema postupcima navedenim u odgovarajućem ISO standardu (BS ISO 25217: 2009). Proračuni se temelje na jednostavnoj grednoj teoriji i linearno-elastičnoj mehanici loma. U ovom radu predstavit ćemo standardnu metodu za izvođenje DCB testa, a potom i metodu obrade podataka potrebnu za izračun lomne žilavosti, što odgovara kritičnoj promjeni oslobođene energije (eng. Critical Energy Release Rate). Eksperimenti su izvedeni za ljepilo SikaPower® 4720, $s$ kontroliranom debljinom ljepila između aluminijskih pločica. Nakon razdoblja stvrdnjavanja prema preporuci proizvođača ljepila, DCB uzorci su preko zglobnog prihvata šarkama opterećeni vlačnom silom s kidalice. Opterećenje na kidalici se nanosi kontrolom pomaka, tako da pri monotonom povećanju pomaka najprije imamo povećanje opterećenja, a kada se pukotina počne širiti, naneseno opterećenje pada. Koristeći optički mjerni sustav GOM Aramis, tijekom eksperimenta mjereno je polje pomaka, koje je onda korišteno za mjerenje stvarnog pomaka aluminijskih pločica (umjesto onog zabilježenog na kidalici) i položaja vrha pukotine. Nakon sinkronizacije mjerenja različitih uređaja određena je lomna žilavost ljepila $i$ izvršena statistička analiza rezultata.

Ključne riječi: test dvostruke konzole, linearno elastična mehanika loma, metoda testiranja, delaminacija u modu-I, lomna žilavost

\section{Introduction}

Determining the fracture resistance of structural adhesives is required for their application in the industry. This is usually done in accordance with relevant standards, such as [1,2], which describe the experimental procedure needed for obtaining the data and the methods used for processing of the data in order to estimate the fracture resistance of the adhesive. All data-processing methods are based on linear elastic fracture mechanics (LEFM) and they return the critical energy release rate as the principal fracture resistance parameter. This parameter can then be used for structural design of laminated composites and adhesive joints capable to withstand adhesive debonding (delamination). Depending on the loading conditions, delamination or debonding can be divided in three basic (pure) modes: opening (mode I), shearing (mode II) and tearing (mode III). In the case of a combination of two or all three modes, we have a so-called mixedmode delamination or debonding. The focus of this paper is only mode-I debonding. 
Double cantilever beam (DCB) test is the standard test for determining the fracture resistance in mode I. Test specimens are made by gluing two equal adherends together in order to expose them to a symmetric opening load during the experiment, thus creating crack propagation along the bonded surface. Applied load, load-line displacement and crack length are continuously measured during the experiment. While the first two parameters can be obtained directly from the tensile-testing machine, for the measurement of the crack length additional optical measuring equipment needs to be used. The data obtained from the experiment is then used to compute the fracture toughness of the adhesive using methods known as data-reduction schemes.

One of the most common ways to characterize the fracture resistance in mode-I is to use the critical energy release rate. This parameter can be determined via simple methods derived from LEFM and cantilever beam deflection expressions based on either Euler-Bernoulli or Timoshenko beam theory. In order to use these methods, one must know the geometry and material parameters of the DCB specimen beforehand and then experimentally measure the values of applied load, load-line displacement and crack length. For each set of measured parameters, fracture resistance can be computed during crack propagation, which is usually presented graphically as the resistance curve (R-curve) [1]. It is expected that, after the initial part of the R-curve, the fracture resistance reaches a plateau which is taken as a representative value for the tested adhesive.

Although it is a relatively simple procedure, determining the fracture resistance using the DCB test has its limitations. Limitations on dimensions of the specimens, thickness of the adhesive and loading rate, just to name a few, are introduced in standards [1,2] to make the simplified theory for the computation of the fracture resistance acceptably (in)accurate. In fact, because LEFM theory can be representative only for very brittle adhesives [3], many data reduction schemes correct the theory to make it valid for a wider range of realistic adhesives (often showing ductile behaviour). One of the most common approaches is to correct the measured crack length, while keeping the measured values of the applied load and the load-line displacement. This approach is adopted in BS ISO 25217:2009 [1], but the method still requires the measurement of the crack length. On the other hand, proposed data-reduction schemes that do not require the measurement of the crack length have been proposed in the literature $[4,5,6]$. In particular, de Moura et al. [7] proposed the so-called "Compliance Based Beam Method" (CBBM), while Škec et al. [8] proposed a method called "Enhanced Simple Beam Theory" (ESBT). Both methods are based on Timoshenko beam theory and the concept of equivalent crack length, but the latter is based on a correct mathematical derivation, which results in a different expression for the fracture resistance. Comparisons made 
using the data from virtual experiments [8] confirm that both methods are extremely accurate (even for ductile adhesives), but ESBT is even more accurate than the most accurate data reduction scheme from DCB standards (CBT from [1]). In this paper, this result is confirmed using the data from real experiments.

The outline of the paper is the following. In Section 2, derivation of expressions for determining the critical energy release rate is given according to a relevant standard [1] and ESBT data-reduction scheme [8]. Preparation and testing of DCB specimens is explained in detail in Section 3. Section 4 presents the results and compare different data-reduction. Finally, in Section 5 the main conclusions are drawn and guidelines for future work are provided.

\section{Data-reduction schemes}

\subsection{Problem description}

Double cantilever beam is made of two metal adherends with length $L$, height $H$ and width $B$, as can be seen in Figure 1 . Adherends are glued together with adhesive of thickness $t$, except on the left side with an initial notch (initial crack) of length $a_{0}$. At the left-hand end, lower adherend is pinned while the upper is loaded by prescribed transversal displacement $\delta$.

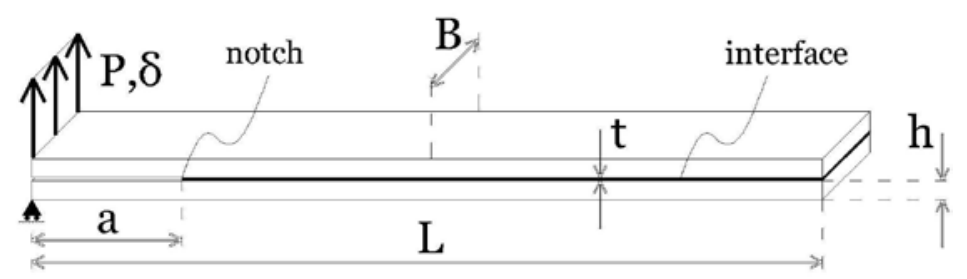

Figure 1. Geometry of a DCB specimen with corresponding boundary conditions and loading

\subsection{Background theory}

G. R. Irwin defined the energy release rate [3] as rate of change in potential energy $\pi$ for an increment of crack area $d A$

$$
G=-\frac{d \pi}{d A}
$$

Crack propagation occurs when $G$ reaches critical value $G_{c}$. Furthermore, it was shown that this value equals 


$$
G_{C}=\frac{P^{2}}{2 B} \frac{d C}{d a}
$$

where $P$ is the force applied, $B$ is the structure width, $C=\delta / P$ is the structure compliance where $\delta$ is the displacement, and $a$ is the crack length.

By using the well-known beam theory expressions for cantilever beam displacement we can calculate the compliance and its derivation over change of fractured area, i.e. we can derive the critical energy release rate Gc. Beam theory displacement formula is given hereafter for both EulerBernoulli theory and Timoshenko theory

$$
\begin{gathered}
\delta^{E}=\frac{P a^{3}}{3 E I} \\
\delta^{T}=\frac{P a^{3}}{3 E I}+\frac{P a}{\mu A k_{s}}
\end{gathered}
$$

where $E$ is the elasticity modulus, $I$ is the moment of inertia, $\mu$ is the shear modulus, $A$ is the cross section, $k_{S}$ is the Timoshenko shear coefficient, $\delta^{E}$ and $\delta^{T}$ are deflection according to Euler-Bernoulli and Timoshenko beam theory, respectively.

\subsection{Data reduction schemes from standards}

ISO 25217:2009 [1] and ASTM-D3433-99 [2] are international standards for determining the fracture resistance in mode I. In the first one [1], three different data-reduction schemes are given, namely: "Simple beam theory" (SBT), "Corrected beam theory" (CBT) and "Experimental compliance method" (ECM). On the other hand, ASTM-D3433-99 contains only one data-reduction scheme that is equivalent to SBT [1]. Therefore, in this paper we will focus on data-reduction schemes given in ISO 25217:2009 and assess their accuracy.

Critical energy release rate given by SBT method is derived from Timoshenko beam theory and LEFM. From equations (2) and (4) we obtain

$$
G_{I C}^{S B T}=\frac{4 P^{2}}{E_{S} B^{2}}\left(\frac{3 a^{2}}{h^{3}}+\frac{1}{h}\right)
$$

This method assumes that DCB adherends act as if they were Timoshenko beams clamped at the crack tip. This implies that the adhesive is infinitely stiff and perfectly brittle, which, of course, can be only a theoretical assumption and by no means a representative behaviour of a real adhesive. It is clear that no adhesive (even an infinitely stiff one) can prevent the rotation of the arms at the crack tip and in front of it if the shear deformability of the arm is taken into account [8]. Moreover, adhesive usually deforms before breaking, which means that there will be 
some compliance at at the crack tip before the crack starts to propagate. Therefore, it is clear that the measured values of $\delta, P$ and $a$ will never satisfy Equation (4). Accordingly, Equation (5), as confirmed in Section 4.2, will not give accurate predictions of adhesive's fracture resistance.

To address the aforementioned inaccuracies of the SBT data-reduction scheme, the critical energy release rate can be calculated using the corrected beam theory (CBT) method, which increases the crack length by a correction $\Delta$, thus increasing the cantilever beam deflection. The critical energy release rate given by CBT method is obtained by substituting expression (3) for Euler-Bernoulli theory in (2), which, by assuming a crack length correction $\Delta$, results in

$$
G_{I C}^{C B T}=\frac{3 P \delta}{2 B(a+|\Delta|)}
$$

According to Equation (3), for a constant stiffness of DCB arms (EI) crack length is proportional to the cubic root of compliance. However, this is valid only if the arms act as if they were Euler-Bernoulli beams clamped at the crack tip. In reality, measured values of $\delta, P$ will never respect Equation (3). However, from the plot of the cubic root of compliance vs. crack length it can be noticed that this can be achieved by simply correcting the crack length by a fixed value $\Delta$. This means that, while keeping the measured values of $\delta$ and $P$, the actual crack length is substituted by a corrected one which makes Equation (3) valid. Therefore, as also confirmed in Section 4.2 , Equation (6) is very accurate.

Last method suggested by ISO 25217:2009 standard is called ECM, and it also aims for experimental correction of the Euler-Bernoulli theory. This method corrects the exponent " 3 " in the formula (3); exponent is obtained experimentally by linear fit of logarithm scale plot of compliance $C$ versus crack length $a$. The slope of the linear fit of the data points is the corrected exponent $\mathrm{n}$. Finally, critical energy release rate given by ECM equals

$$
G_{I C}^{E C M}=\frac{n P \delta}{2 B a}
$$

\subsection{Enhanced simple beam theory method}

As we have seen earlier, all data reduction schemes from relevant standard require the measurement of crack length $a$. In recent developed method, called "Enhanced simple beam theory" (ESBT) [8], such measurement is not necessary. Firstly, the assumption that the cross section of the DCB adherends do not rotate at the crack tip is discarded, but the rotation caused by shear deformation is introduced instead. According to the derivation presented in [8], the correct expression for the load-line displacement for the case of Timoshenko beam theory and LEFM reads 


$$
\delta=2\left(\frac{P a^{3}}{3 E I}+\frac{P a(1+a \sqrt{\alpha)}}{\mu A_{s}}\right)
$$

This expression, like expressions (3) and (4), is valid only for the LEFM limit case. In reality, the measured values of $\delta, P$ and a will never satisfy Equation (8). However, by introducing the concept of equivalent crack length $a_{e q}$, crack length measurement becomes unnecessary and the experiment is significantly simplified. By solving cubic equation (8), $a$ can be expressed as a function of $\delta$ and $P$. This means that for any value of measured compliance $\delta / P$, we can compute the equivalent crack length (not the measured one) that makes expression (8) valid using the following expression

$$
a_{e q}=\sqrt[3]{\left(\frac{1}{\sqrt{\alpha}}\right)^{3}+\frac{3 E I \delta}{2 P}}-\frac{1}{\sqrt{\alpha}} ; \alpha=\frac{\mu A_{s}}{E I}
$$

Finally, the energy release rate by ESBT method is obtained by combining expressions (8) and (2), and substituting $a$ with $a_{e q}$, giving

$$
G_{I C}^{E S B T}=\frac{P^{2}}{b}\left(\frac{a_{e q}^{2}}{E I}+\frac{1+2 a_{e q} \sqrt{\alpha}}{\mu A_{S}}\right)
$$

\section{Experiment}

\subsection{Preparation of test specimen}

In this paper we used aluminium adherends and epoxy glue SikaPower® 4720. Metal adherends dimensions are chosen by taking into account the approximate fracture resistance of the adhesive so that no plastic deformation of metal adherends occurs. Before the specimen preparation is started, the loading system should be designed so that forces can be transferred from tensile-testing machine to the DCB specimen. In this paper, we use the piano hinges system, as seen in Figure 6. The compliance of the DCB specimen has a significant effect on the deflection measured on the tensile-testing machine, so it is advisable to use hinges of sufficient stiffness to make the compliance negligible.

We start by numbering the metal adherends and then measuring their thickness with vernier calipers, at the middle and at both ends. The side of the adherends on which the adhesive will be applied must be prepared beforehand, with treatment depending on the type of the adhesive. In this paper, we roughened the surface with sandpaper and then cleaned it with acetone. To form the initial crack, the aluminium foil is inserted at the beginning of the specimen to introduce the initial crack of length . 
Bonding is performed according to the manufacturer's instructions. It is a common practice to throw away the initially squeezed part of the two-component adhesive, except in case of manual mixing. We applied the adhesive to the sample by a putty knife, so that the putty knife slides on the guide rails to control the thickness of the adhesive layer (Figure 2). It is recommended that the thickness of one layer is approximately about $1 \mathrm{~mm}$.

When the adhesive is applied on both sides, the specimens are combined, while the thickness of the adhesive layer is carefully controlled by a $0.5 \mathrm{~mm}$ thick fishing line (Figure 3). Specimen may then be pressed manually to achieve better contact and extrusion of the excess glue.

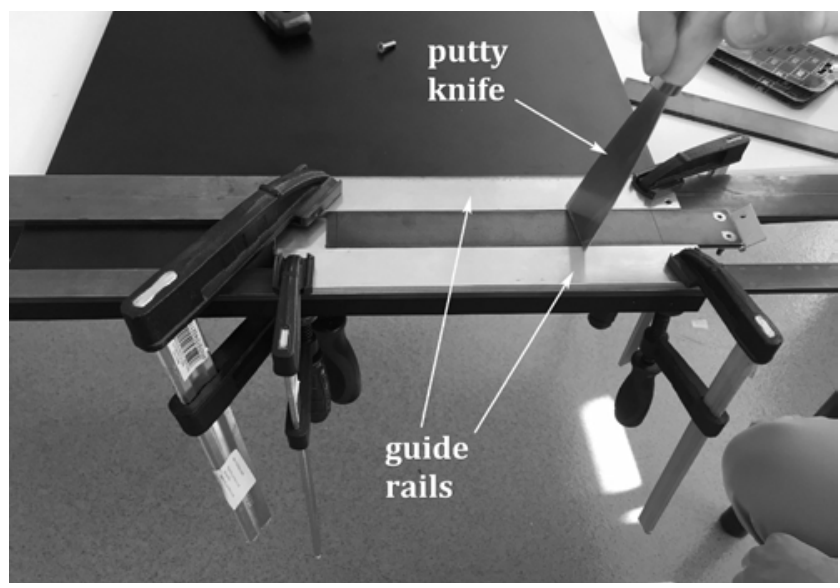

Figure 2. Application of adhesive by putty knife on guide rails

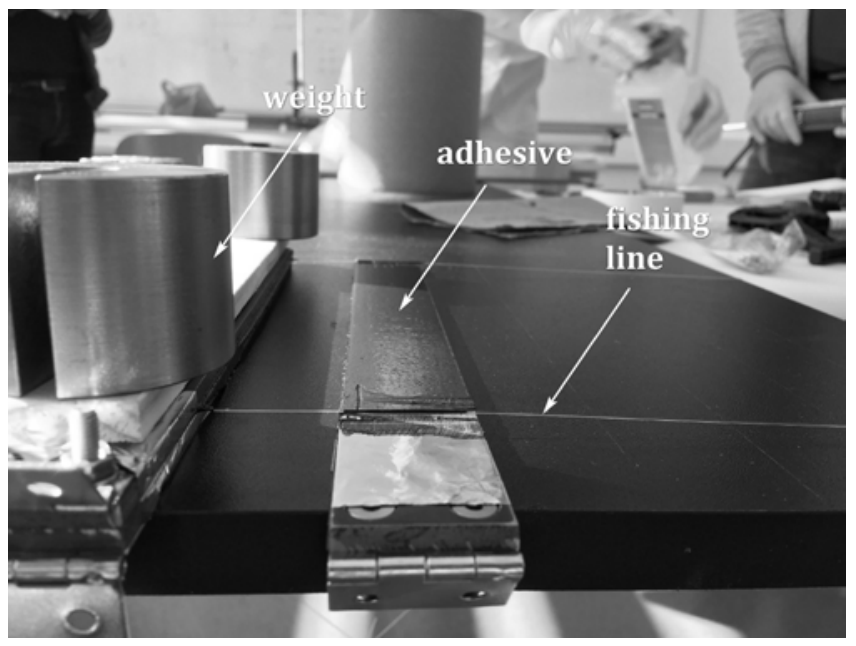

Figure 3. Setup with fishing line for controlling the adhesive thickness 
All specimens, minimum 4 according to [1], are then clamped and loaded with weight during the prescribed curing period. If needed, the process itself can be accelerated for epoxy glue by drying at higher temperatures in the oven. Finally, the adhesive thickness is calculated as the difference between the thickness of the cured specimens and the thickness of the plates before gluing. Adhesive layer thickness $t_{3}$ (see Table 1 ) is the thickness measured at specimen end near the piano hinges. A deviation in the thickness within a specimen should be no more than $20 \%$ according to the criteria [1]. The enlarged picture of the adhesive thickness can be seen in Figure 4. It can be noticed that the fishing-line technique was successful in keeping the minimum adhesive thickness greater than $0.5 \mathrm{~mm}$, but, due to the lack of pressure applied on the plates and the viscosity of the adhesive, there was some adhesive between the fishing line and the plates that resulted in thickness greater than $0.5 \mathrm{~mm}$. However, the maximum deviation of the specimen thickness was smaller than the limit of $20 \%$, except for the specimen A30-01 (see Table 1), which will consequently show slightly different results in the section 4.2. It is important for the adhesive to be homogeneous as possible throughout the interface because the lack of adhesive in some areas may result in lower value of fracture toughness.

Table 1. Deviation of thickness

\begin{tabular}{|l|c|c|c|c|c|}
\hline & $\begin{array}{c}t_{1} \\
{[\mathrm{~mm}]}\end{array}$ & $\begin{array}{c}t_{2} \\
{[\mathrm{~mm}]}\end{array}$ & $\begin{array}{c}t_{3} \\
{[\mathrm{~mm}]}\end{array}$ & $\begin{array}{c}t_{\text {average }} \\
{[\mathrm{mm}]}\end{array}$ & $\begin{array}{c}\text { Maximum } \\
\text { deviation }\end{array}$ \\
\hline A30-01 & 0.51 & 0.63 & 0.70 & $\mathbf{0 . 6 1}$ & $\mathbf{2 7 \%}$ \\
\hline A30-02 & 0.56 & 0.69 & 0.65 & $\mathbf{0 . 6 3}$ & $\mathbf{1 9 \%}$ \\
\hline A30-03 & 0.66 & 0.61 & 0.69 & $\mathbf{0 . 6 5}$ & $\mathbf{1 2 \%}$ \\
\hline A30-04 & 0.68 & 0.66 & 0.72 & $\mathbf{0 . 6 9}$ & $\mathbf{8 \%}$ \\
\hline
\end{tabular}

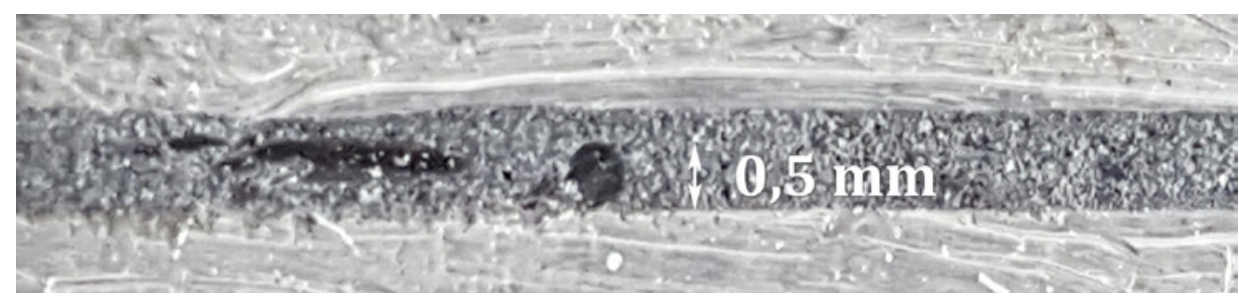

Figure 4. Enlarged photograph of the interface edge

In this paper, instead of recording experimental results by personal visual inspection as suggested in [1,2], the experiment is recorded with optical measuring equipment (cameras) and processed by digital image 
correlation (DIC) method. To do this, specimen must be painted with a stochastic black and white pattern (Figure 5), which can then be used to retrieve full-field data such as displacement field. This part of the specimen preparation is paramount because, in case of a poor pattern quality, there is a risk of optical measurement equipment not recognizing any movement or deformation of the specimen. Quality of stochastic pattern depends on several factors such as camera settings, calibration, non-reflective surface patterns, size of stochastic dots on the sample, frequency of recording.

DIC full field data is derived from captured grayscale raster graphics, where every pixel is represented by its lightness ranging from value 0 (black pixel) up to value 255 (white pixel). Triangulation can be used to determine the position of the same pixel during the experiment. For full field data, square areas in the image, called facets, are used. Pixels lightness of one facet is interpolated by a 2D spline. Undeformed and deformed state is then correlated by deformation mapping, finally yielding full-field displacement and strain over time [9].
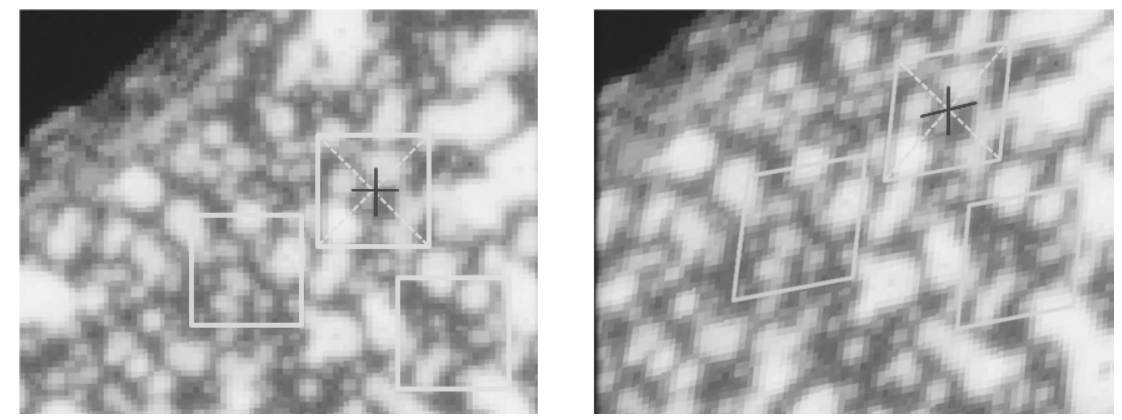

Figure 5. DIC facets (undeformed and deformed state)

\subsection{Experiment procedure}

Manufactured specimens are mounted in the tensile-testing machine (Figure 6) and then the cameras, placed at the prescribed separation distance [9], are pointed to the specimen in a way that throughout the experiment the specimen stays in the frame. Before starting the experiment, it is advisable to take a photograph of the initial frame to check the recognition of the stochastic pattern on the computer program GOM Aramis (DIC software).

The prescribed displacement speed is constant throughout the experiment, and the speed used here is $2 \mathrm{~mm} / \mathrm{min}$. Speed used here meets DIC requirements because displacement during a single exposure is small enough for sharp photos without any presence of motion blur, ensuring precise measurements. The precision of crack length measurement is prescribed [1] to $+/-0.5 \mathrm{~mm}$. The theoretical deviation in optical precision 
measurement is the order of 0.1 pixel size, which in this paper translates to about $+/-0.01 \mathrm{~mm}$. Moreover, it should also be noted that, in comparison to visual inspection of crack length, the method used here is not affected by human error in measurement.

Testing starts with the launch of the tensile-testing machine and with the start of optical recording. After the specimen fracture, the samples are dissected and can then be photographed to determine the type of fracture, which may be adhesive fracture or cohesive fracture. Any fracture irregularities, such as adhesive fracture, can then be recognized on the specimen (see Figure 7) and on the graph of fracture resistance (Figure $10)$. In the present paper, cohesive failure was dominant in all specimens.

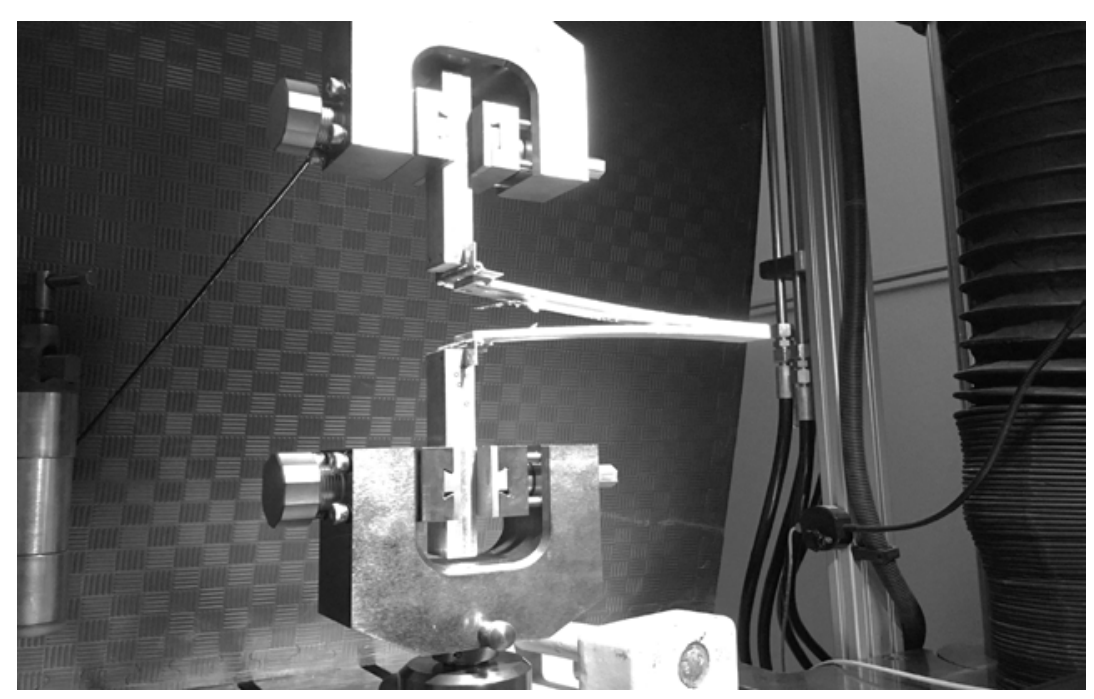

Figure 6. Double cantilever beam experiment

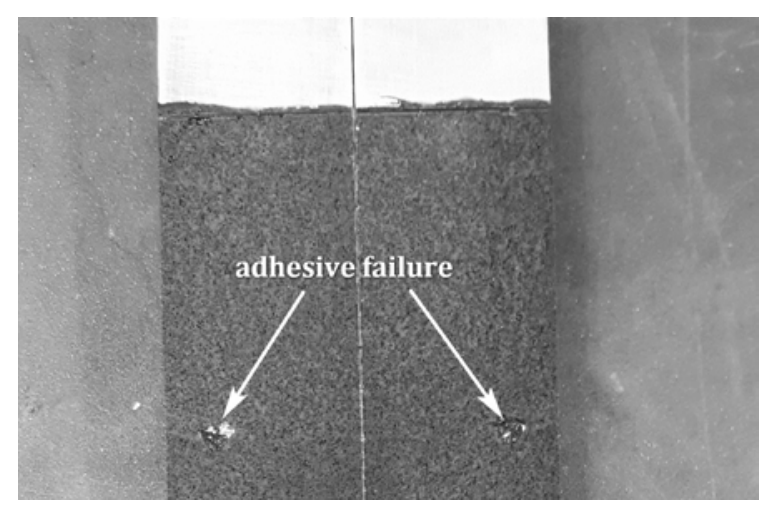

Figure 7. Broken adhesive interface after the test (specimen A30-01) 


\section{Results}

\subsection{Measurement processing}

Distance between the adherends axes is constructed in the GOM Aramis software for each optical measurement frame (Figure 8). Crack in the adhesive is defined in a way that the crack length corresponds to the distance at which the adherends relative displacement is smaller than the predetermined size. For example, one can define this value as 0.02 $\mathrm{mm}$, which corresponds to maximum elongation of 3\% (according to the technical sheet) for the adhesive thickness of $0.5 \mathrm{~mm}$. Another approach is to define this relative displacement as the size at which we can see the crack by visual inspection, e.g. relative displacement value that we have used in this paper: $0,3 \mathrm{~mm}$. This approach depends on human estimation and is subject to error, nonetheless it is the approach accepted in international standards [1,2]. Measurements of the tensile testing machine and the GOM Aramis are then synchronized. It is advisable to use the optically measured displacement $\delta$ to avoid any faults due to the compliance of the system.

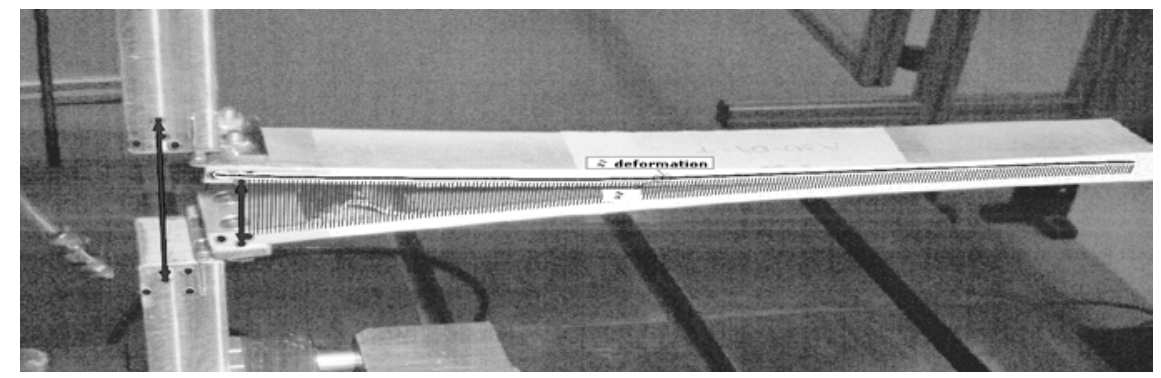

Figure 8. DIC measurement

\subsection{Comparison of results}

Figure 9 shows force versus displacement data for all four specimens. Values show good agreement across all specimens, which means that the specimens were prepared in an accurate and consistent manner. Occasional drops in the curves can be attributed to defects in the adhesive layer.

Fracture resistance comparison of SBT, CBT, ECM and ESBT is given in Table 2 and in the graph form in Figure 10. The results from Table 2 indicate that the adhesive behaves uniformly on the test specimens. Figure 10 shows a so-called resistance curve ( $\mathrm{R}$ curve) that describes a change in fracture resistance during crack propagation. It is apparent that the SBT method significantly deviates from the other methods because the measured crack length is used without correction in the formula for $G_{I C}$ 
(5). Although it uses a correction coefficient, neither ECM is capable to reach the plateau of the fracture resistance. Obtained R-curves show a very similar behaviour to that reported in $[4,10]$ where ESBT and CBT always closely coincide and give values that are close to the plateau of the fracture resistance, SBT gives significantly lower values of the fracture resistance, while ECM has a decreasing trend in fracture resistance during crack propagation and never reaches its plateau. Moreover, it can be noted that, similar to what has been reported in [10], a rising R-curve is observed only for SBT.

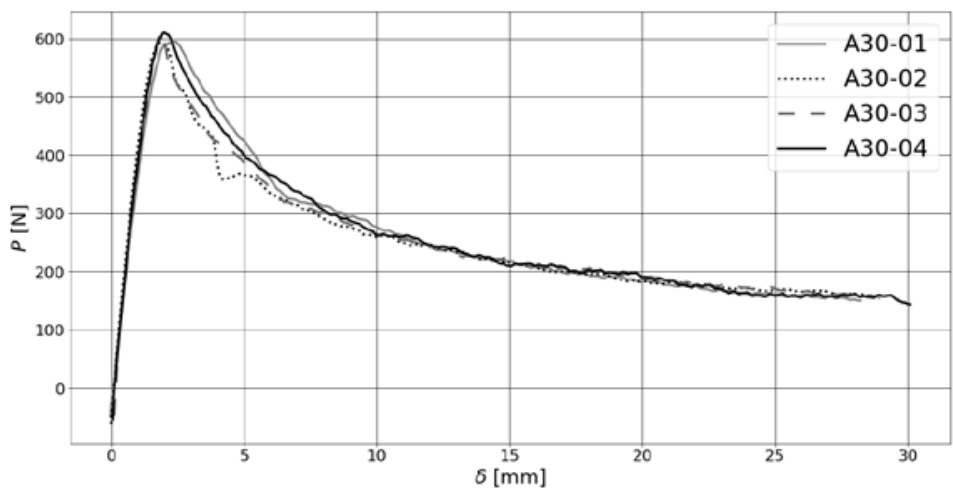

Figure 9. Force vs displacement graph for all four specimens

Higher deviation of adhesive layer thickness for the specimen A3001 (Table 1) can now be recognized on the R-curve where the higher $G_{I C}$ matches the higher adhesive layer thickness. Furthermore, interfacial failure visible on the broken interface of the same specimen in Figure 7 can now be recognised as a drop in the R-curve.

Table 2. Critical energy release rate in $\left[\mathrm{J} / \mathrm{m}^{2}\right]$

\begin{tabular}{|c|c|c|c|c|c|c|}
\hline Sample & A30-01 & A30-02 & A30-03 & A30-04 & Average & $\begin{array}{c}\text { Standard } \\
\text { deviation }\end{array}$ \\
\hline SBT & 748.49 & 697.49 & 713.19 & 711.40 & 717.64 & 18.82 \\
\hline CBT & 1073.40 & 1032.50 & 1048.64 & 1082.89 & 1059.36 & 19.92 \\
\hline ECM & 1049.95 & 996.01 & 993.01 & 1033.28 & 1018.06 & 24.30 \\
\hline ESBT & 1047.92 & 1017.12 & 1039.11 & 1050.41 & 1038.64 & 13.11 \\
\hline
\end{tabular}



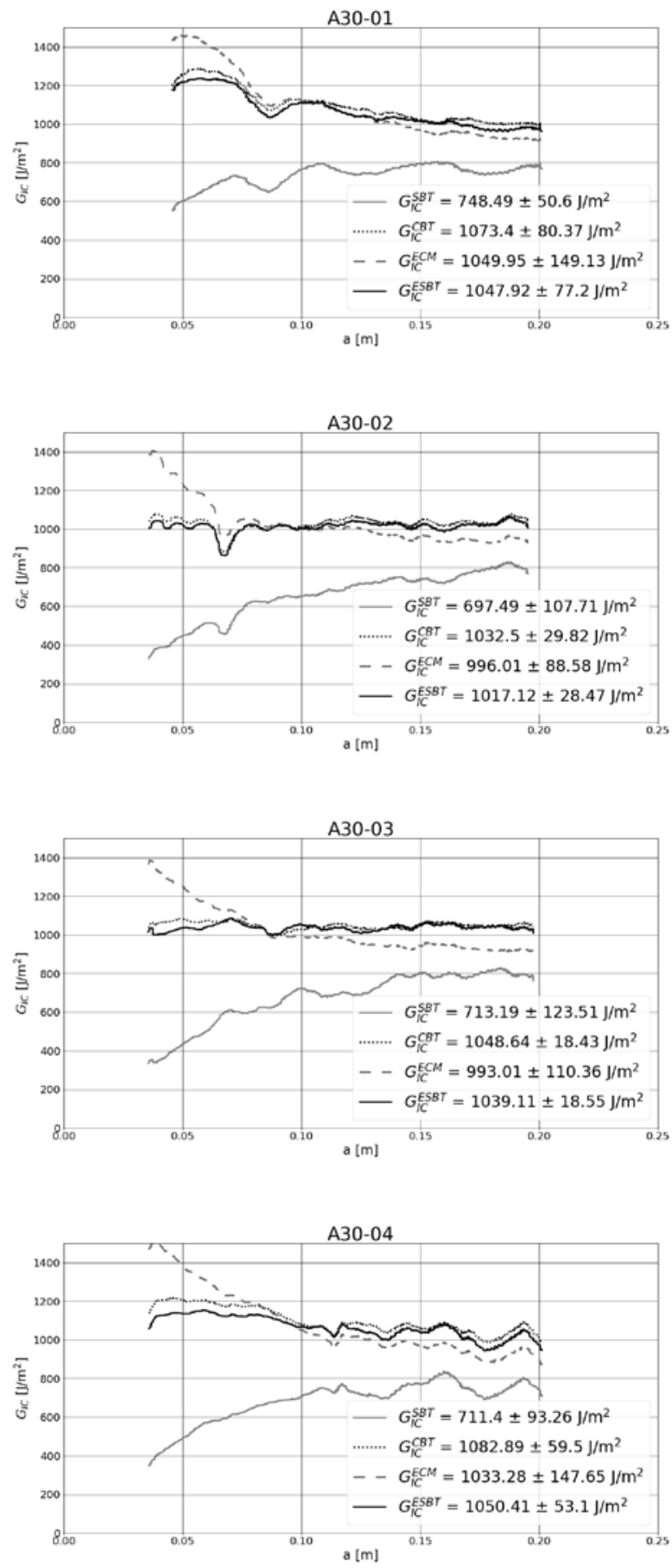

Figure 10. R-curves for all four specimens 
For better readability of results shown on Figure 10, a simple median filter with a window size of 21 is implemented. Figure 10 also presents mean value and standard deviation generated from nearly 2000 captured data points for each specimen. It is evident that ESBT yields the smallest standard deviation of the mean fracture resistance in four samples (Table 2 ), and in one sample, it yields a minimal deviation from the mean fracture resistance (Figure 10).

\section{Conclusion}

In this paper, determination of fracture resistance of SikaPower $\AA^{\circledR} 4720$ adhesive was performed according to BS ISO 25217 (2009) [1] and ESBT data-reduction scheme [8]. Crack length was measured with the help of DIC technology instead of visual inspection. By analyzing the experimental results, we concluded that the recently developed ESBT method yields similar results to CBT method from the standard [1]. These two methods showed best agreement with fracture toughness definition as plateau in the R-curve diagram. Distinct benefit of ESBT over CBT is that it does not require the crack length measurement.

Therefore, a new version of the standard for the DCB test should seriously take into account data-reduction schemes, such as ESBT, that do no require the measurement of the crack length. By doing so, the experimental procedure could be significantly simplified since the optical measurement equipment is not necessary.

Acknowledgements. The results shown here have been obtained within the research project IP-06-2016-4775: "Assumed strain method in finite elements for layered plates and shells with application on layer delamination problem - ASDEL" financially supported by the Croatian Science Foundation from 2017. The authors would also like to acknowledge Sika Croatia for their support.

\section{References}

[1] British Standards Institution BS ISO 25217. (2009) "Adhesives Determination of the Mode 1 Adhesive Joints Using Double Cantilever Beam and Tapered Double Cantilever Beam Specimen". British Standard.

[2] ASTM D3433-99. (2012) Standard Test Method for Fracture Strength in Cleavage of Adhesives in Bonded Metal Joints. ASTM International.

[3] Anderson, T.L., (1995) Fracture Mechanics - Fundamentals and Applications, 2nd ed. CRC Press.

[4] Tamuz, V., Tarasovs, S., Vilks, U. (2003) "Delamination Properties of Translaminar-Reinforced Composites", Compos. Sci. Technol. 63, 1423-1431. 
[5] Biel, A., Stigh, U. (2007) "An Analysis of the Evaluation of the Fracture Energy Using the DCB-Specimen", Arch. Mech. 59 (4-5), 311-327.

[6] Alfano, M., Furgiuele, F., Pagnotta, L., Paulino, G. (2011) "Analysis of Fracture in Aluminum Joints Bonded with a Bi-Component Epoxy Adhesive", J. Test. Eval. 39 (2), 1-8.

[7] de Moura, M.F.S.F., Campilho, R.D.S.G., Gonçalves, J.P.M. (2008) “Crack Equivalent Concept Applied to the Fracture Characterization of Bonded Joints under Pure Mode I Loading", Compos. Sci. Technol. 68, 2224-2230.

[8] Škec, L., Alfano, G., Jelenić, G., (2019) "Enhanced Simple Beam Theory for Characterizing mode-I Fracture Resistance via a Double Cantilever Beam Test”“', Compos. Part B Eng. 167, 250-262.

[9] Aramis V8 SR1 Manual Basic, (2015) GOM mbH Aramis.

[10] Škec, L., Alfano, G., Jelenić, G., (2018) “On , and the Characterization of the Mode-I Fracture Resistance in Delamination or Adhesive Debonding", Int. J. Fract., 144-145, 100-122. 